\title{
Assessment of Cropping Pattern and Productivity of Crops under the Telugu Ganga Project Command Area in Andhra Pradesh by Using Remote Sensing and GIS
}

\author{
C.H. Murali Krishna ${ }^{\text {* }}$, M.V. Ramana ${ }^{2}$, H.V. Hema Kumar ${ }^{3}$, \\ B. Ramana Murthy ${ }^{4}$ and N.V. Sarala ${ }^{5}$ \\ ${ }^{1}$ Department of Soil and Water Engg, SV. Agricultural College, Tirupati, India \\ ${ }^{2}$ Department of Soil and Water Engg, Dr NTR CAE, Bapatla, India \\ ${ }^{3}$ ARS, Perumalla Palli, Chittoor (District), India \\ *Corresponding author
}

Keywords

TGP, RS and GIS,

Cropping area,

Cropping pattern,

Productivity and

Command area

\section{Article Info}

Accepted:

20 September 2020

Available Online:

10 October 2020

\section{A B S T R A C T}

The Telugu Ganga Irrigation Project is in drought prone areas of Rayalaseema region comprising of Chittoor, Kadapa, Kurnool and uplands of Nellore in Andhra Pradesh. Assessed the changes in the area of different crops grown in kharif, rabi and the total area of crops in the entire Telugu Ganga Project (TGP) command in Andhra Pradesh in South India using Remote Sensing (RS) and Geographic Information System (GIS) techniques. The changes in the crop area (ha) and percentage change in the area have been assessed in kharif and rabi seasons of 1997 and 2018 and also when pooled over the two seasons in the entire TGP command comprising of four districts of Chittoor, Nellore, Kurnool and Kadapa. We have also observed significant changes in the shifts in the early, medium and late sown area of the most pre-dominant paddy crop during the study period. The paddy area has significantly increased from 1997 to 2018 based on our research study. On the whole, there was a significant increase in the area of paddy, apart from groundnut, sugarcane and other crops grown indifferent mandals in the four districts located under the TGP command. The results based on our research study are useful to the Government for efficient crop planning in different districts of Andhra Pradesh.

\section{Introduction}

The Telugu Ganga Irrigation Project is an inter-state Project formulated to irrigate 5.75 lakh acres in drought prone areas of Rayalaseema region comprising of Chittoor,
Kadapa, Kurnool and uplands of Nellore in Andhra Pradesh by utilizing 29 TMC of water from Krishna flood flows, and 30 TMC of water from Pennar river flood flows. Crop area estimation at village level would require a replacement with a suitable technology 
implementation. The Remote Sensing based spatial data analysis would significantly improve the estimates to reality since the spatial information is captured on a temporal basis, and quantification on the crop areas at disaggregated level is possible. Based on a massive irrigation infrastructure is existing in Andhra Pradesh, a huge irrigation potential has been created in the state over years.

The satellite data would greatly provide scope for synoptic coverage and multi-temporal datasets. Most of the Indian and global satellites have been providing medium resolution data at fortnightly/monthly intervals which would provide continuity in data acquisition. The Landsat and Indian Remote Sensing (IRS) Resources at are popular and useful in this category. Satellite data offers many advantages for mapping of irrigated area at temporal and spatial scales (2015) studied to estimate the area of kharif crops using Landsat- 8 data of satellite images (Ahmad et al., 2016). However, for making effective use of remote sensing, the analyst should be aware of limitations and advantages of using satellite data, and choose appropriate strategy from available irrigation mapping options. Our present research study is focused on demonstrating the methodology for analyzing the irrigation potential utilization both for large and small projects by processing public domain satellite data. The findings of the study would help the Government for adopting time and cost effective modes

\section{Materials and Methods}

\section{Rainfall patterns in the entire TGP Command}

The annual rainfall (mm) of Telugu Ganga Project (TGP) command area in Andhra Pradesh ranged from $675 \mathrm{~mm}$ to $933 \mathrm{~mm}$ in the study period compared to historical normal rainfall of $1134 \mathrm{~mm}$. The South-West monsoon would play a significant role on the productivity of different crops grown during the kharif season. The North-East monsoon would account for the remaining 25 to $30 \%$ of annual rainfall every year.

The three cropping seasons in the four districts in the TGP command area are Kharif (June-September), Rabi (October-December) and summer (January-April). The rice based cropping systems are quite pre-dominant in the Telugu Ganga Project area grown during Kharif season, while black gram, green gram, groundnut, soyabean and chilies would be grown under the rice fallows during the rabi season with the available residual moisture in the soil. But sugarcane crop would be grown throughout the year during both kharif and rabi seasons. Rice crop is mostly grown by the traditional method of growing the nursery and transplanting in the main field with a continuous flooding of irrigation water.

In the present research study, it is proposed to evaluate the performance of the Telugu Ganga irrigation project area, which has been spread across the four districts viz, Chittoor, Nellore, Kadapa and Kurnool with a total number of 33 mandals and irrigation ayacut area of 575000 ha in Andhra Pradesh state based on different performance indicators. The study area is depicted in Figure 1. The command area along with the mandal-wise details are provided in Table 1.

\section{Results and Discussion}

\section{Remote sensing data}

In India, the satellite data would provide a lot of scope for efficient coverage and multitemporal datasets. The Indian and global satellites have been providing medium resolution data at 15-days/ 30-days intervals which would provide a continuity for data 
acquisition. The Landsat and Indian Remote Sensing (IRS) Resources at are popular and useful in this category. In our research study, Sentinel 2a has been used for carrying out the work for the starting period (1997) and the ending period (2018). These two years have been considered because the Telugu Ganga Project has started releasing the water from 1997 onwards, while 2018 is the actual year of our research study. The remote sensing images for these two periods were also found to be clear and hage free compared to other years.

\section{The Landsat 4}

The Landsat $4 \mathrm{tm}$ has been used for carrying out a mapping and analysis for 1997.The technical specifications of the Landsat 4 is given in Table 2.Based on an updated design compared to the previous three missions, the satellite has carried out the Multi-Spectral Scanner (MSS) as well as the new Thematic Mapper (TM) instruments. The sensors that are fixed onboard in the satellite have collected the data until late 1993, and the satellite was decommissioned on $15^{\text {th }}$ June, 2001.Accordingly, the Multi-Spectral Scanner (MSS) and the new Thematic Mapper (TM) sensors were carried out by the Landsat 4 .

Some of the major specifications of the LISS III camera and characteristics of the IRS IC, LISS III sensor and IRS P6 are given in Table 3. The LISS III sensor camera would provide the multi-spectral data in 4 bands. The spectral revolution for the visible (two bands) and also the near infrared (one band) would be $30 \mathrm{~m}$ with a swath of $185 \mathrm{~km}$. The fourth band (short wave infrared band) has a spectral resolution of $30 \mathrm{~m}$ with ground swath of 185 $\mathrm{km}$. The receptivity of the LISS III is 16 days.

\section{The collection of topo sheets and Ancillary maps}

The Survey of India 1:50000 topo sheets have been used for identification of various features in the imagery and also for the georeferencing of the imagery. The study area of Telugu Ganga Project is described in Fig. 1. The irrigation and drainage map was obtained from the Department of Irrigation, Government of Andhra Pradesh. The canal and drainage network map is given in Fig. 2. It has been used to identify various commands in the Telugu Ganga Project area in the study period.

The crop mapping and assessment of the acreage using the Remote Sensing(RS) and Geographic Information System (GIS) techniques used in the TGP command have been depicted in Fig. 3. These images would provide critical information during the crop condition assessment. The water body maps in the study area are shown in Fig. 4, for both Kharif and Rabi seasons of 1997 and 2018respectively. The crop condition could be determined based on the NDVI ranges in the maximum NDVI as obtained based on the above procedure. In general, they would be categorized as very good $(>0.5)$, good $(0.4-$ $0.5)$ and average crop conditions $(<0.4)$ based on the NDVI values (Chwenming and Muhrong, 1998).

\section{Change in remote sensing based area of crops in the entire TGP command}

Using remote sensing technique, the area (ha) of 9 different crops viz., paddy, groundnut, sugarcane, jowar, cotton, sunflower, bajra, pulses and chillies has been assessed in the entire TGP Command during kharif and rabi seasons. The total area (ha) of crops observed during 1997 is depicted in Fig. 8. The area (ha) of crops observed based on the remote sensing technique during the kharif and rabi seasons of 1997 and 2018 and the changes (\%) that have occurred in the area of crops over years in the entire TGP Command are given in Table 4 . The change $(\%)$ in area of crops was found to range from $-72.8 \%$ for groundnut to $390.7 \%$ for paddy in kharif 
season, while it ranged from $-70.8 \%$ for sugarcane to $280.6 \%$ for paddy in rabi season. The change in total area of crops during both kharif and rabi seasons was found to range from $-63.6 \%$ for bajra to $435.0 \%$ for pulses during 1997 to 2018 (Fig. 5 and 6).

Table.1 Mandals of different districts and the irrigation ayacut area in the TGP Command area

\begin{tabular}{|l|c|l|}
\hline District & $\begin{array}{c}\text { Irrigation } \\
\text { Ayacut (Acres) }\end{array}$ & List of mandals \\
\hline Chittoor & 98000 & $\begin{array}{l}\text { (i) Thottambedu (ii) B.N.Kandriga (iii) KVB Puram } \\
\text { (iv) Varadaiahpalem (v) Satyavedu }\end{array}$ \\
\hline Kadapa & 177000 & $\begin{array}{l}\text { (i) Atluru (ii) B. Koduru (iii) Badvelu (iv)B.Matham } \\
\text { (v) Duvvuru (vi) Gopavaram (vii) Kalasapadu (viii) Khajipeta } \\
\text { (ix) Porumamilla (x) Narasapur (SAKN) (xi) Mydukur }\end{array}$ \\
\hline Nellore & 245674 & $\begin{array}{l}\text { (i) Venkatagiri (ii) Balayapalli (iii) Pellakuru (iv) DV Satram } \\
\text { (v) Tada (vi) Naidupeta (vii) Chittamuru (viii) Vakadu }\end{array}$ \\
\hline Kurnool & 54326 & $\begin{array}{l}\text { (i) Velugodu (ii) Bandi Atmakur (iii) Mahanandi } \\
\text { (iv) Nandyal (v) Sirivella (vi) Rudravaram (vii) Allagadda } \\
\text { (viii) Chagalamarri (ix) Gospadu }\end{array}$ \\
\hline Total & 575000 & 33 mandals \\
\hline
\end{tabular}

Table.2 The technical specifications of the Landsat 4

\begin{tabular}{|l|l|}
\hline Landsat 4 & \multicolumn{2}{l|}{} \\
\hline Mission type & Earth imaging \\
\hline Operator & NASA / NOAA \\
\hline Spacecraft properties & \multicolumn{1}{|l|}{} \\
\hline Bus & Multi-mission Modular Spacecraft \\
\hline Manufacturer & GE Astro Space \\
\hline Launch mass & 1941 kilograms $(4279 \mathrm{lb})$ \\
\hline Dry mass & 1407 kilograms $(3102 \mathrm{lb})$ \\
\hline Start of mission & \\
\hline Launch date & $16^{\text {th }}$ July 1982 \\
\hline Rocket & Delta 3920 \\
\hline Launch site & Vandenberg AFB SLC-2W \\
\hline End of mission & \\
\hline Deactivated & $15^{\text {th }}$ June 2001 \\
\hline Orbital parameters & \\
\hline Reference system & Geocentric \\
\hline Regime & Sun-synchronous \\
\hline Perigee altitude & 700 kilometers $(430 \mathrm{mi})$ \\
\hline Apogee altitude & 704 kilometers $(437 \mathrm{mi})$ \\
\hline Inclination & 98.2 degrees \\
\hline Period & 98.81 minutes \\
\hline Repeat interval & 16 days \\
\hline
\end{tabular}


Table.3 Major specifications of the IRS IC and LISS III Camera

\begin{tabular}{|c|c|c|c|}
\hline \multirow{2}{*}{ Sentinel-2 Bands } & \multirow{2}{*}{ Central Wavelength $(\mu \mathrm{m})$} & \multirow{2}{*}{ Resolution (m) } & \multirow{2}{*}{$\begin{array}{l}\text { Astrium/Airbus } \\
\text { Thales Alenia Space }\end{array}$} \\
\hline & & & \\
\hline Band 1 - Coastal aerosol & 0.443 & 60 & Boostec \\
\hline Band 2 - Blue & 0.490 & 10 & Jena-Optronik \\
\hline Band 3 - Green & 0.560 & 10 & SENSOR \\
\hline Band 4 - Red & 0.665 & 10 & \\
\hline Band 5 - Vegetation Red Edge & 0.705 & 20 & \\
\hline Band 6 - Vegetation Red Edge & 0.740 & 20 & \\
\hline Band 7 - Vegetation Red Edge & 0.783 & 20 & \\
\hline Band 8 - NIR & 0.842 & 10 & \\
\hline Band $8 \mathrm{~A}$ - Vegetation Red Edge & 0.865 & 20 & \\
\hline Band 9 - Water vapour & 0.945 & 60 & \\
\hline Band 10 - SWIR - Cirrus & 1.375 & 60 & \\
\hline Band 11 - SWIR & 1.610 & 20 & \\
\hline Band 12 - SWIR & 2.190 & 20 & \\
\hline \multicolumn{4}{|l|}{ Manufacturer } \\
\hline \multicolumn{3}{|l|}{ Operator } & European Space Agency \\
\hline \multicolumn{3}{|l|}{ Applications } & $\begin{array}{l}\text { Land and sea monitoring, natural disasters } \\
\text { mapping, sea ice observations, ships detection }\end{array}$ \\
\hline \multicolumn{4}{|l|}{ Specifications } \\
\hline \multicolumn{3}{|l|}{ Spacecraft type } & Satellite \\
\hline \multicolumn{3}{|l|}{ Bus } & AstroBus-L \\
\hline \multicolumn{3}{|l|}{ Constellation } & 2 \\
\hline \multicolumn{3}{|l|}{ The Design life } & 7 years \\
\hline \multicolumn{3}{|l|}{ Launch mass } & $1140 \mathrm{~kg}(2513 \mathrm{lb})$ \\
\hline \multicolumn{3}{|l|}{ Dry mass } & 1016 kg (2240 lb) \\
\hline \multicolumn{3}{|l|}{ The Dimensions } & $3.4 \times 1.8 \times 2.35 \mathrm{~m}(11.2 \times 5.9 \times 7.7 \mathrm{ft})$ \\
\hline \multicolumn{3}{|l|}{ Power } & $1700 \mathrm{~W}$ \\
\hline \multicolumn{4}{|l|}{ Production } \\
\hline \multicolumn{3}{|l|}{ Status } & Active \\
\hline \multicolumn{3}{|l|}{ Built } & 2 \\
\hline \multicolumn{3}{|l|}{ Launched } & 2 \\
\hline \multicolumn{3}{|l|}{ Operational } & 2 \\
\hline \multirow{2}{*}{\multicolumn{3}{|c|}{ Maiden launch }} & Sentinel-2A \\
\hline & & & $23^{\text {rd June }} 2015$ \\
\hline \multirow{2}{*}{\multicolumn{3}{|c|}{ Last launch }} & Sentinel-2B \\
\hline & & & $7^{\text {th }}$ March 2017 \\
\hline
\end{tabular}


Table.4 Remote sensing based area (ha) of major crops grown during kharif and rabi seasons in the entire TGP command area.

\begin{tabular}{|l|l|c|c|c|c|c|c|}
\hline Year & Crop & \multicolumn{3}{|c|}{ Area (ha) } & \multicolumn{3}{c|}{ Change (\%) in area } \\
\hline & & Kharif & Rabi & Total & Kharif & Rabi & Total \\
\hline $\mathbf{1 9 9 7}$ & Paddy & 53674 & 25014 & 78688 & & & \\
\hline & Groundnut & 16055 & 19126 & 35181 & & & \\
\hline & Sugarcane & 4297 & 4376 & 8673 & & & \\
\hline & Jowar & 0 & 24707 & 24707 & & & \\
\hline & Cotton & 17660 & 0 & 17660 & & & \\
\hline & Sunflower & 0 & 14601 & 14601 & & & \\
\hline & Bajra & 3199 & 0 & 3199 & & & \\
\hline & Pulses & 1875 & 0 & 1875 & & & \\
\hline & Chillies & 13442 & 0 & 13442 & & & \\
\hline & Total & 110202 & 87824 & 198026 & & & \\
\hline $\mathbf{2 0 1 8}$ & Paddy & 85138 & 95213 & 180351 & 58.6 & 280.6 & 129.2 \\
\hline & Groundnut & 4368 & 11784 & 16152 & -72.8 & -38.4 & -54.1 \\
\hline & Sugarcane & 2834 & 1279 & 4113 & -34 & -70.8 & -52.6 \\
\hline & Jowar & 6742 & 17476 & 24218 & 0 & -29.3 & -2 \\
\hline & Cotton & 14942 & 0 & 14942 & -15.4 & 0 & -15.4 \\
\hline & Sunflower & 0 & 16100 & 16100 & 0 & 10.3 & 10.3 \\
\hline & Bajra & 1163 & 0 & 1163 & -63.6 & 0 & -63.6 \\
\hline & Pulses & 9201 & 831 & 10032 & 390.7 & 0 & 435 \\
\hline & Chillies & 3852 & 14568 & 18420 & -71.3 & 0 & 37 \\
\hline & Total & 128240 & 157251 & 285491 & 16.4 & 79.1 & 44.2 \\
\hline
\end{tabular}

Table.5 Yield of major crops (kg/ha) attained in different districts and the entire TGP command area

\begin{tabular}{|c|l|c|c|c|c|c|}
\hline S.no & Crop & Chittoor & Nellore & Kurnool & Kadapa & Entire TGP Command \\
\hline $\mathbf{1}$ & Paddy & 4156 & 4562 & 3812 & 3282 & 3953 \\
\hline $\mathbf{2}$ & Groundnut & 1200 & 2928 & 989 & 1004 & 1530 \\
\hline $\mathbf{3}$ & Sugarcane (q/ha) & 891.29 & 995.1 & 0 & 0 & 943.2 \\
\hline $\mathbf{4}$ & Jowar & 0 & 0 & 1725 & 1308 & 1517 \\
\hline $\mathbf{5}$ & Cotton & 0 & 0 & 1358 & 0 & 1358 \\
\hline $\mathbf{6}$ & Chillies (q/ha) & 0 & 0 & 167.18 & 0 & 167.18 \\
\hline $\mathbf{7}$ & Sunflower & 0 & 0 & 0 & 1136 & 1136 \\
\hline $\mathbf{8}$ & Blackgram & 1062 & 647 & 0 & 0 & 855 \\
\hline $\mathbf{9}$ & Bajra & 2475 & 0 & 0 & 0 & 2475 \\
\hline $\mathbf{1 0}$ & Greengram & 0 & 655 & 0 & 0 & 655 \\
\hline
\end{tabular}

* sugarcane and chillies yield are given in $\mathrm{q} / \mathrm{ha}$; and other crop yields are given in $\mathrm{kg} / \mathrm{ha}$ 
Table.6 Assessment of shifting of kharif and rabi area (ha) of the pre-dominant paddy crop as an early, medium and late sown crop during 1997 and 2018

\begin{tabular}{|l|l|c|c|c|}
\hline Year & Season & Early & Medium & Late \\
\hline $\mathbf{1 9 9 7}$ & Kharif & 24153.3 & 21469.6 & 8051.1 \\
\hline & Rabi & 11256.3 & 10005.6 & 3752.1 \\
\hline & Total & 35409.6 & 31475.2 & 11803.2 \\
\hline $\mathbf{2 0 1 8}$ & Kharif & 25541.4 & 42569.0 & 17027.6 \\
\hline & Rabi & 28563.9 & 47606.5 & 19042.6 \\
\hline & Total & 54105.3 & 90175.5 & 36070.2 \\
\hline Change $\mathbf{( \% )}$ & Kharif & 5.75 & 98.28 & 111.49 \\
\hline & Rabi & 153.76 & 375.8 & 407.52 \\
\hline & Total & 52.8 & 186.5 & 205.6 \\
\hline
\end{tabular}

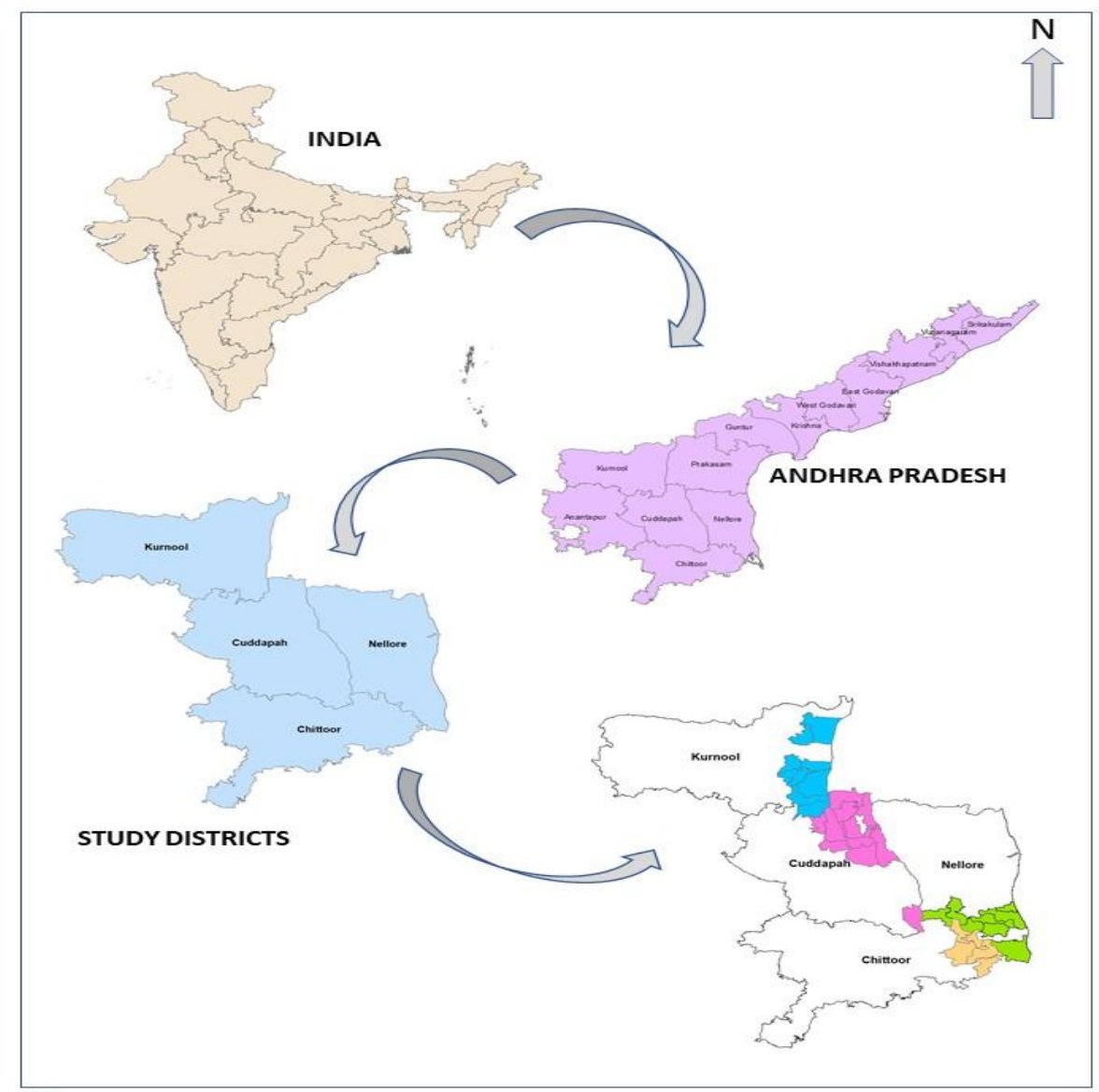

Figure.1 Study area of Telugu Ganga Project 


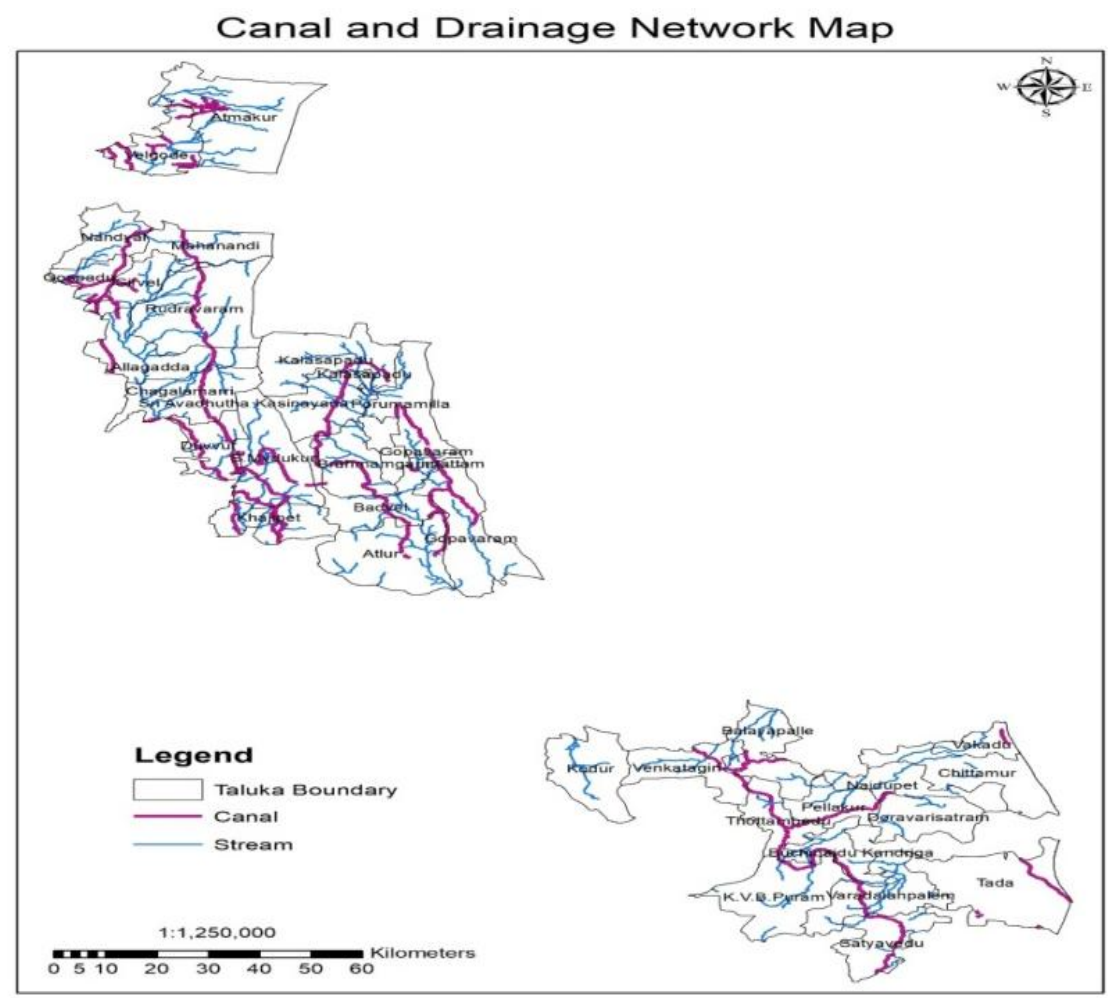

Figure.2 Canal and Drainage network map in TGP command

\section{CROP MAPPING AND ACREAGE ESTIMATION USING RS AND GIS \\ TECHNIQUE}

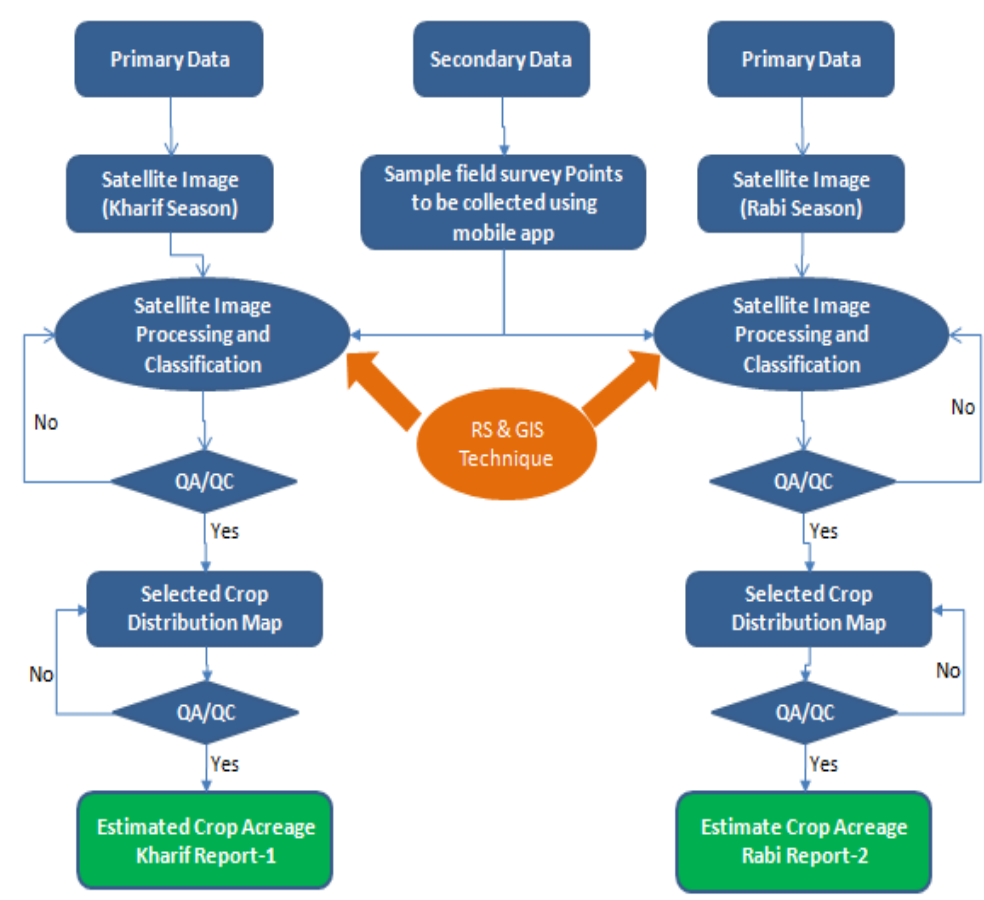

Figure.3 Crop mapping and assessment of acreage using the RS and GIS techniques 


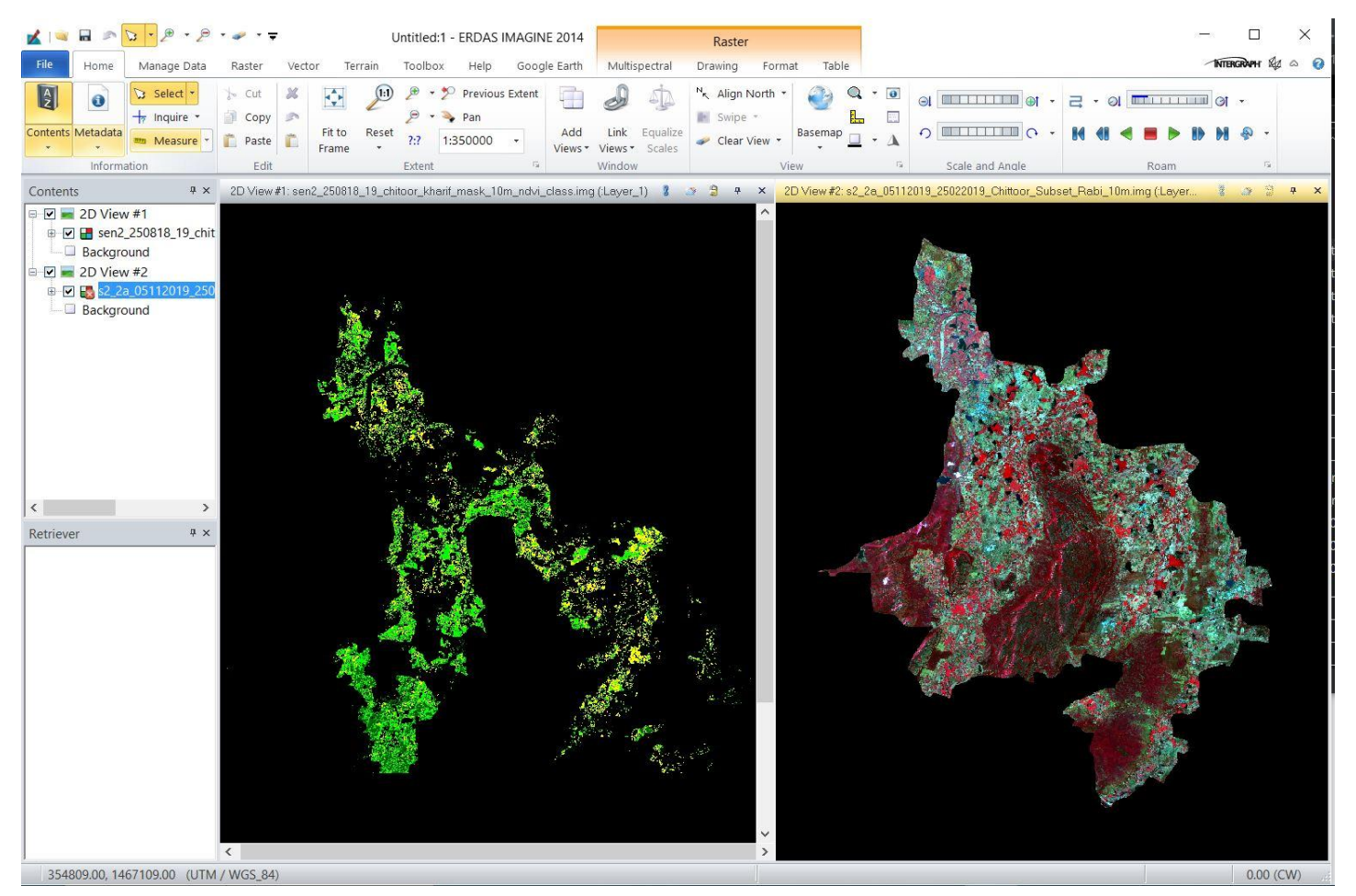

Figure.4 Remote sensing working window of ERDAS software

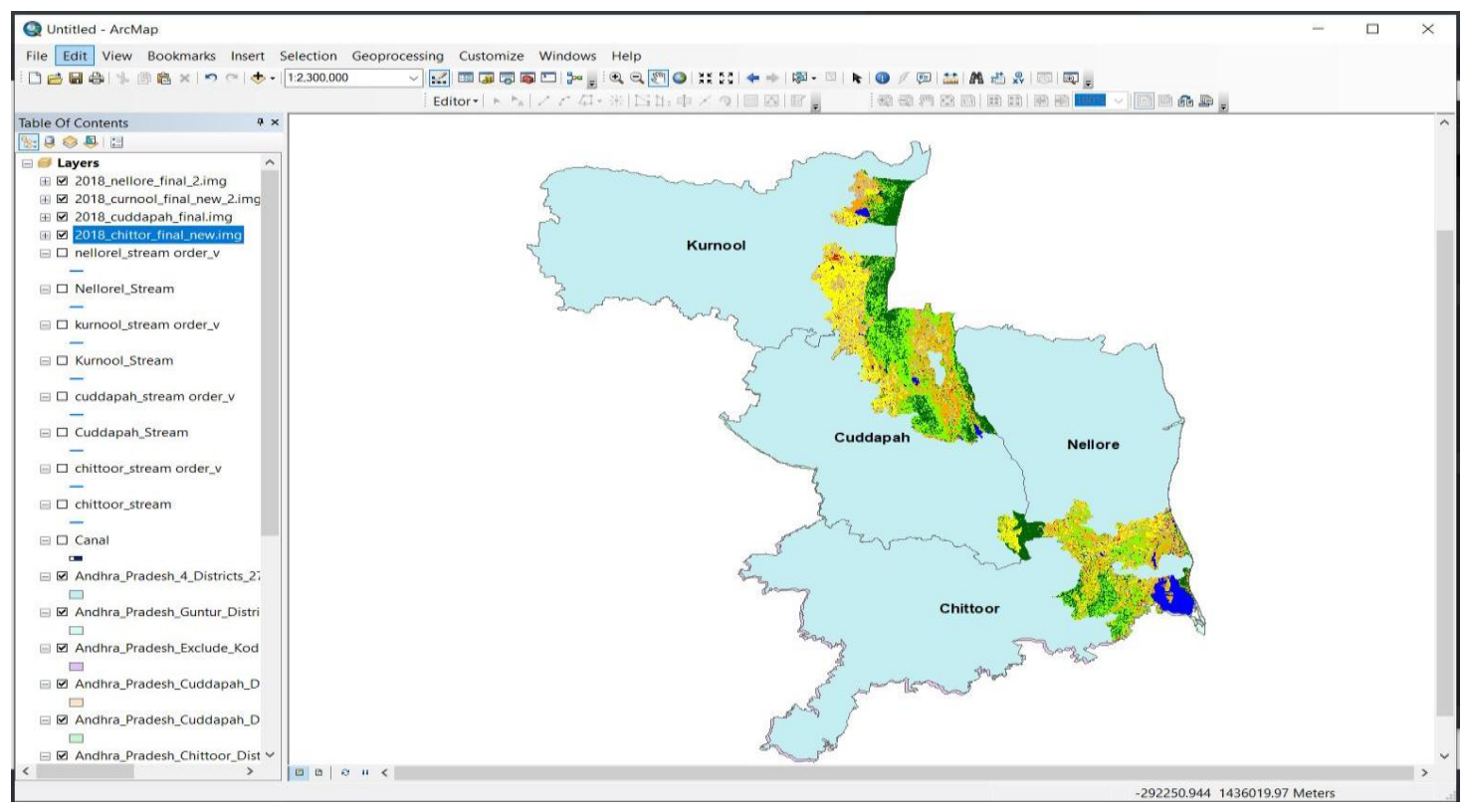

Figure.5 Remote Sensing image of entire TGP command area 


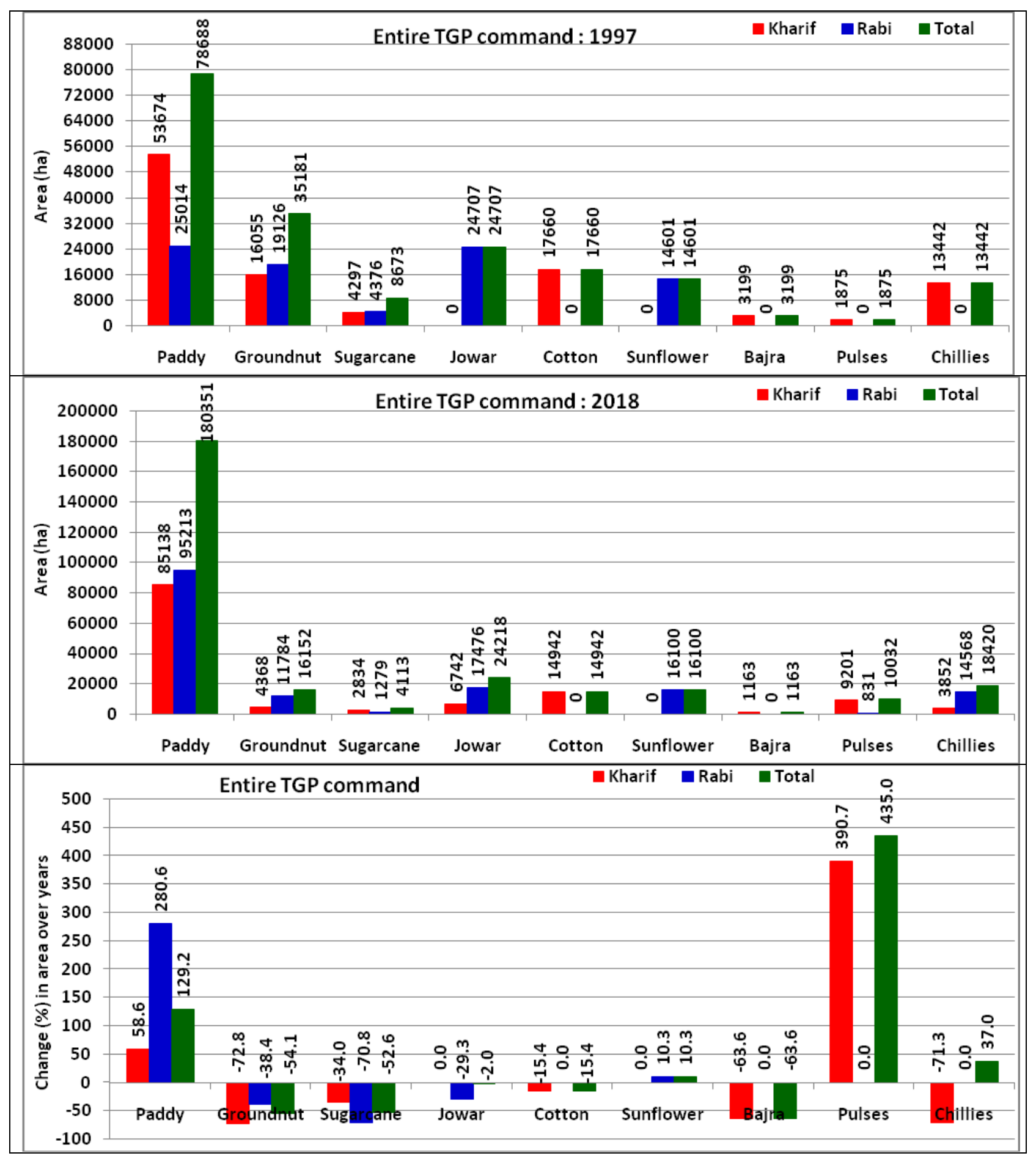

Figure.6 Remote sensing based area (ha) of crops grown during kharif and rabi seasons in the entire TGP command during 1997 and 2018 


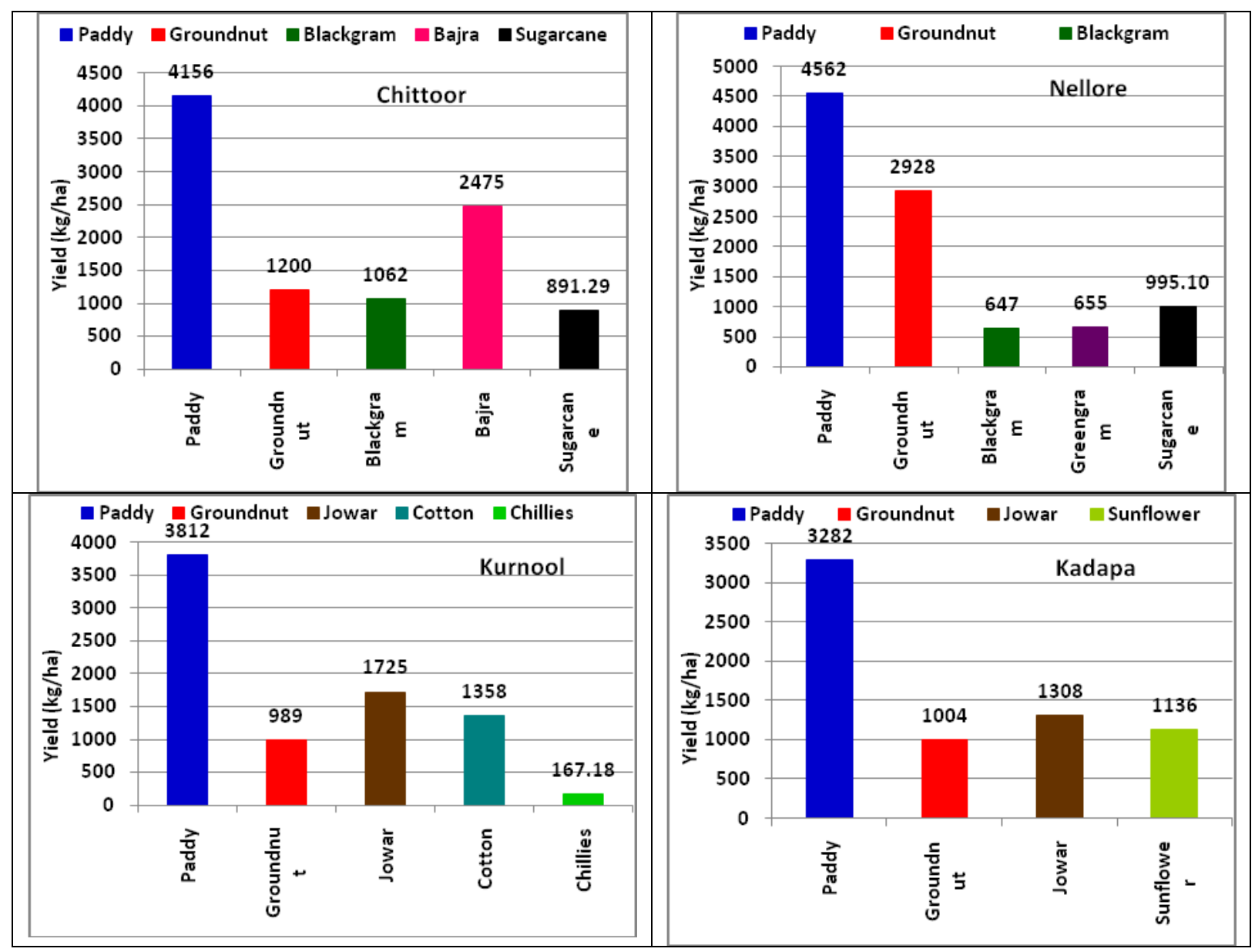

Figure.7 Yield of major crops attained in four districts in the TGP Command (all crop yields are in $\mathrm{kg} / \mathrm{ha}$; chillies and sugarcane yield are inq/ha)

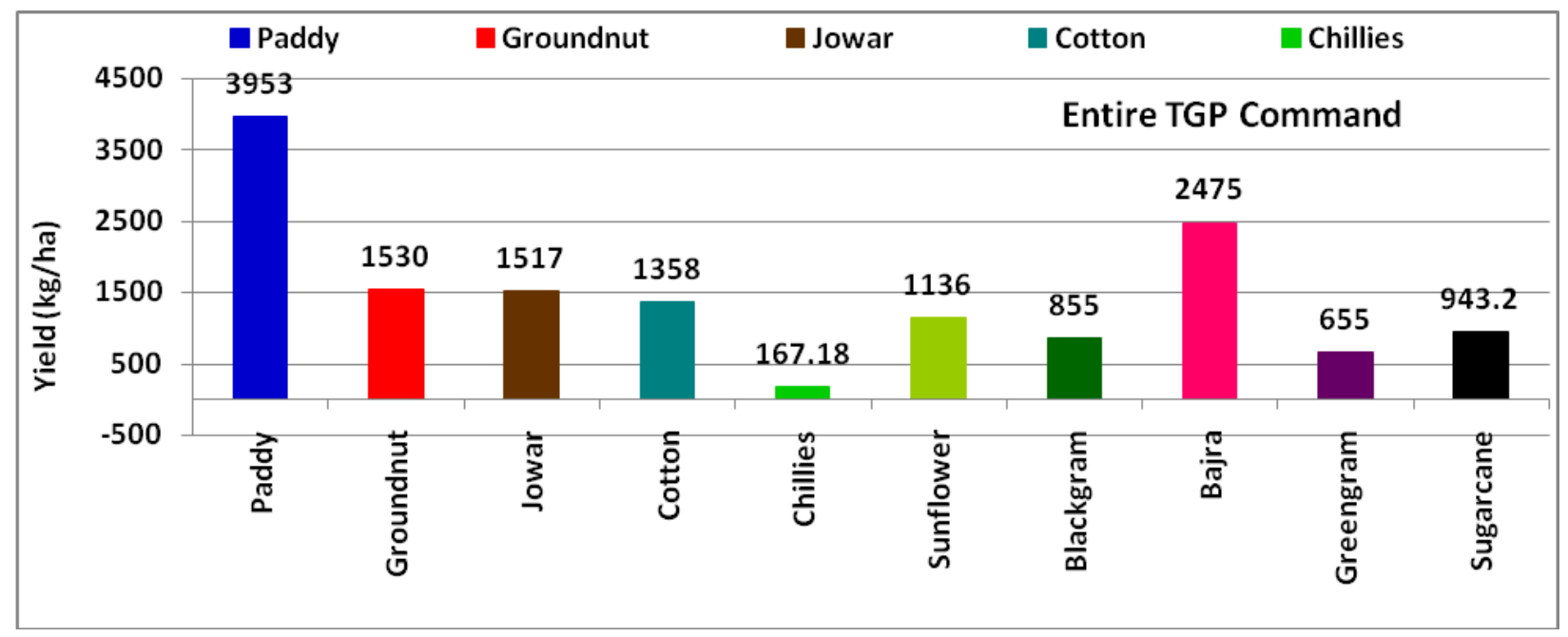

Figur.8 Yield of different crops attained in the entire TGP Command (all crop yields are in $\mathrm{kg} / \mathrm{ha}$; chillies and sugarcane yield are inq/ha) 


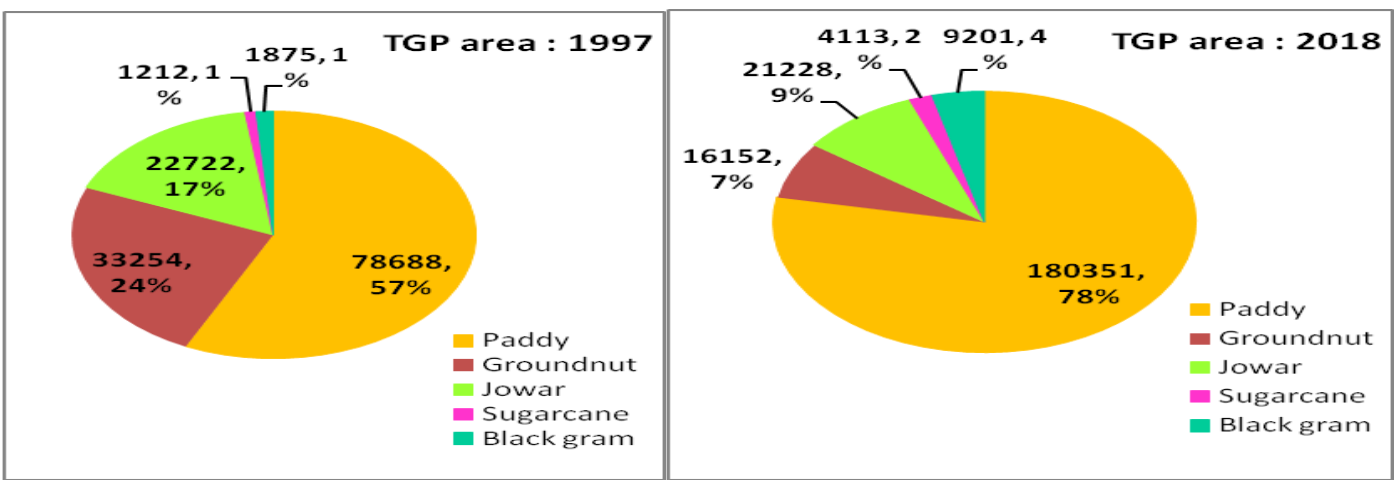

Figure.9 Shift in area (\%) of different crops in entire TGP command based on Remote Sensing data during 1997 and 2018

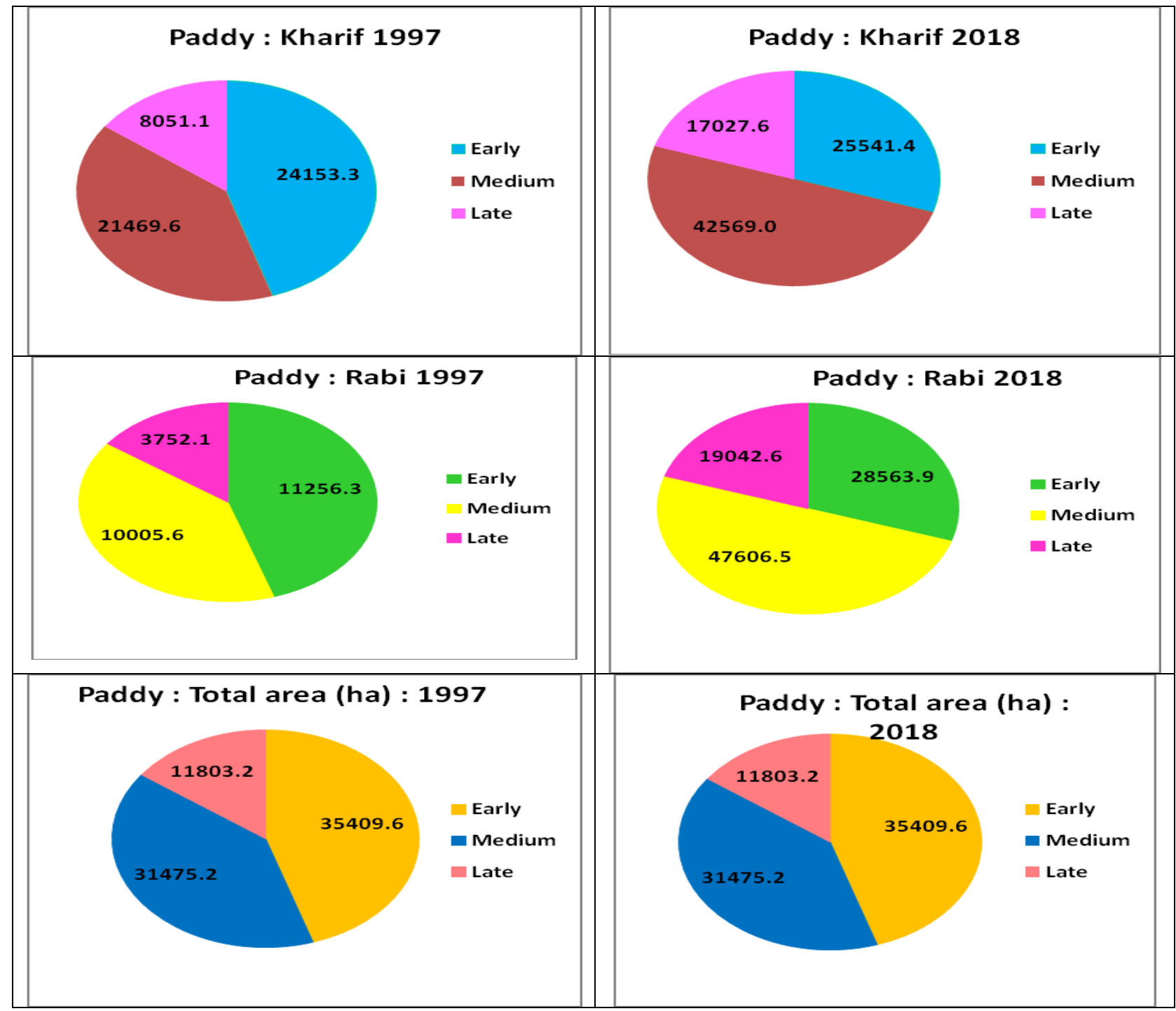

Figure.10 Shift in the Early, Medium and Late sowing area of paddy in Kharif and Rabi seasons and the total area in the entire TGP command based on Remote Sensing during 1997 and 2018 


\section{Assessment of yield of crops in different} districts

Maximum image of the NDVI during the rabi season of 2018 based on the remote sensing based satellite data has been used. This has been done in order to assess about the nature of relationships existing between the NDVI and yield attained by different crops. The yield data of crops was also collected from the Directorate of Statistics and Economics, Government of Andhra Pradesh (2019) and are given in Table 5.

\section{Yield of crops attained in different districts and entire TGP Command}

The yield of major crops attained in the four districts of the TGP command viz., Chittoor, Nellore, Kurnool and Kadapa are depicted in Fig. 7. Based on the pooled data of crops grown in the four districts under the entire TGP command during the study period, the yields of different crops are depicted in Fig. 10. There were 10 crops grown in the entire TGP command area based on the study, viz., paddy, groundnut, jowar, cotton, chillies, sunflower, black gram, bajra, green gram and sugarcane. The pooled analysis over the four districts has clearly indicated that the mean paddy yield of $3953 \mathrm{~kg} / \mathrm{ha}$ was attained, followed by bajra with $2475 \mathrm{~kg} / \mathrm{ha}$, groundnut with $1530 \mathrm{~kg} / \mathrm{ha}$, jowar with $1517 \mathrm{~kg} / \mathrm{ha}$, cotton with $1358 \mathrm{~kg} / \mathrm{ha}$, sunflower with $1136 \mathrm{~kg} / \mathrm{ha}$, black gram with $855 \mathrm{~kg} / \mathrm{ha}$ and green gram with $655 \mathrm{~kg} / \mathrm{ha}$. In case of sugarcane, yield of $943.2 \mathrm{q} / \mathrm{ha}$ was attained, while in case of chillies crop, yield of $167.18 \mathrm{q} / \mathrm{ha}$ was attained over years in the entire TGP Command area (Fig. 9).

\section{Changes in the shifts of sowing of crops}

The shift in cropping area (\%) of 5 different crops viz., paddy, groundnut, jowar, sugarcane and black gram in the entire Telugu Ganga Project command area during 1997 to 2018 are depicted in Fig. 11.

During 1997, paddy was found to have an area of 78688 ha $(57 \%)$, followed by groundnut with an area of 33254 ha (24\%), jowar with an area of 22722 ha (17\%), black gram with an area of 1875 ha (1\%) and sugarcane with an area of 1212 ha (1\%). Compared to this, during 2018, paddy was found to have an area of 180351 ha (78\%), while jowar had an area of 21228 ha (9\%), groundnut had an area of 16152 ha $(7 \%)$, black gram had an area of 9201 ha (4\%) and sugarcane had an area of 4113 ha (2\%).

In view of the satellite based remote sensing data, the shift in area (\%) of different crops in the entire TGP command using the Remote Sensing data during 1997 and 2018 has been depicted in Fig. 12. The changes in shifting of kharif and rabi sowing of paddy, and the total area of kharif and rabi seasons during the early, medium and late sowings made during 1997 and 2018 are given in Table 6.

In case of paddy grown in the kharif season, the early, medium and late sown area as shown Table 6 has changed from an extent of 24153.3 ha, 21469.6 ha and 8051.1 ha during 1997 and 25541.4 ha, 42569.0 ha and 17027.6 ha during 2018 respectively. Similarly, in the rabi season, the early, medium and late sown area has changed from an extent of 11256.3ha, 10005.6 ha and 3752.1 ha during 1997 and 28563.9 ha, 47606.5 ha and 19042.6 ha during 2018 respectively. Thus the total area of kharif and rabi seasons has changed from 35409.6 ha in 1997 to 54105.3 ha in 2018 with a change of $52.8 \%$ under the early sowings, 31475.2 ha in 1997 to 90175.5 ha in 2018 with a change of $186.5 \%$ under the medium sowings, and 11803.2 ha in 1997 to 36070.2 ha in 2018 with a change of $205.6 \%$ under the late sowings based on the study.

Hence concluded, based on a research study, remote sensing based changes in the area of different crops grown in kharif, rabi and the total area of crops in the entire Telugu Ganga Project command in Andhra Pradesh. The changes in the crop area and percentage in the area have been assessed in each season and also over seasons in the entire TGP command. A significant shift was found to exist in the early, 
medium and late sown area of paddy in different districts of the TGP command during the study period. The paddy area has significantly increased during 1997 to 2018 based on the study. On the whole, there was a significant change in the area of paddy and other crops grown under the TGP command in the four districts of Chittoor, Nellore, Kurnool and Kadapa in the state. The findings based on our research study would help the Government of Andhra Pradesh for adopting time and cost effective methods for water management, apart from efficient crop planning, and increase in the area of crops in different districts in the state.

\section{Acknowledgement}

The authors express their gratitude to the Vice Chancellor, Acharya NG Ranga Agricultural University, Andhra Pradesh for providing financial and technical support for successful completion research.

\section{References}

Ahmad, M.D., Turral, H and Nazeer, A. 2009. Diagnosing irrigation performance and water productivity through satellite remote sensing and secondary data in a large irrigation systems of Pakistan. Agricultural water Management. 99(1): 551-564.

Ahmad, T., Sahoo, P.M and Jally, S.K. 2016. Estimation of area under agroforestry using high resolution satellite data. Agro forest Systems. 90: 289-303.

Bastiaanssen, W. G. M., Thiruvengadachari, S., Sakthivadivel, R and Molden, D. J. 1998. Satellite remote sensing for estimating productivities of land and water. Water
Resources Development. 15(1/2): 181196.

Chakraborti, A.K., Rao, V.V., Shankar, M. and Suresh babu, A.V. 2002. Performance evaluation of an Irrigation project using satellite remote sensing, GIS and GPS. Map India 2002, $5^{\text {th }}$ International conference on Geographic information. 06-08. February 2002, New Delhi. www.mapindia.org.

Kumar, P. R. M., Pradeep, P. L., Chiragkumar, I.P. and Bhura, S. 2015. Command area management study of Karjan Dam Gujarat, India using Remote Sensing and GIS. International Journal of Science Technology \& Engineering.1 (11):161168.

Mulianga, B., Begue, A., Simoes, M. and Todoroff, P., 2013. Forecasting regional sugarcane yield based on time integral and spatial aggregation of MODIS NDVI. Remote Sensing, 5(5): 2184-2199.

Ramana, M. V. 2007. Performance evaluation of canal irrigation systems using Remote sensing and GIS. Ph.D. Thesis. Tamil Nadu Agricultural University, Coimbatore, India.

Reddy, K.M.S. 2016. Assessment of Irrigation Potential utilization in Irrigation Projects using Remote Sensing and GIS. Ph.D. Thesis. Acharya N.G. Ranga Agricultural University, Guntur, Andhra Pradesh.

Sharma, M.P., Yadav, M., Yadav, K., Prawasi, R., Kumar, P., Hooda, R.S. 2011. Cropping System Analysis Using Remote Sensing \& GIS: A Block Level Study of Kurukshetra District. J. Agric. Biol. Sci. 6 (10): 45-61.

\section{How to cite this article:}

C.H. Murali Krishna, M.V. Ramana, H.V. Hema Kumar, B. Ramana Murthy and Sarala, N.V. 2020. Assessment of Cropping Pattern and Productivity of Crops under the Telugu Ganga Project Command Area in Andhra Pradesh by Using Remote Sensing and GIS. Int.J.Curr.Microbiol.App.Sci. 9(10): 2542-2555. doi: https://doi.org/10.20546/ijcmas.2020.910.306 